\title{
HARMONIC COMPONENTS ESTIMATION IN POWER SYSTEM USING BACTERIAL FORAGING OPTIMIZATION ALGORITHM AND STOCHASTIC GRADIENT ALGORITHM WITH VARIABLE FORGETTING FACTOR
}

\author{
Ahmad Mohammadzadeh, Jalil SAdati*, ANd Behrooz Rezaie \\ Department of Electrical \& Computer Engineering, \\ Babol University of Technology, \\ Babol, Iran.
}

ahmad.mohammadzade7@gmail.com; j.sadati@nit.ac.ir; and brezaie@nit.ac.ir

(Received: 11 May. 2015; Accepted: 15 Sept. 2015; Published on-line: 30 Apr. 2016)

\begin{abstract}
In this paper, a hybrid configuration algorithm called stochastic gradient method with variable forgetting factor (SGVFF) is proposed to better estimate unknown parameters in a power system such as amplitude and phase of harmonics using variable forgetting factor following the bacterial foraging optimization algorithm (BFO). It must be mentioned that harmonic estimation is a nonlinear problem and using linear optimization algorithms for solving this problem reduces the convergence speed. Thus, $\mathrm{BFO}$ algorithm is used for initial estimation. In this paper, first, using little information and by applying BFO algorithm in an off-line procedure initial value for SGVFF algorithm is achieved and then SGVFF algorithm is gained in an on-line procedure. In the hybrid algorithm applied in this paper, amplitudes and phases are estimated simultaneously. Simulation results indicate that the proposed method has faster convergence speed, better performance and higher accuracy in a noisy system in comparison with recursive least squares variable forgetting factors algorithm (RLSVFF). This proves the superiority of the proposed method.
\end{abstract}

ABSTRAK: Dalam kertas ini, algoritma konfigurasi hibrid yang dipanggil stokastik kaedah kecerunan dengan faktor lupaan berubah-ubah (SGVFF) dicadangkan untuk anggaran parameter yang tidak diketahui lebih baik dalam sistem kuasa seperti amplitud dan fasa harmonik menggunakan faktor lupaan pembolehubah diikuti dengan algoritma pengoptimuman mencari makan bakteria (BFO). Harus dinyatakan bahawa anggaran harmonik adalah masalah bukan linear dan menggunakan algoritma pengoptimuman linear untuk menyelesaikan masalah ini mengurangkan kelajuan penumpuan. Oleh itu, algoritma BFO digunakan untuk anggaran awal. Pertama, dengan menggunakan sedikit maklumat dan algoritma BFO dalam prosedur luar talian, nilai awal untuk algoritma SGVFF dicapai dan kemudian algoritma SGVFF diperolehi dalam prosedur dalam talian. Dalam algoritma hibrid yang digunakan dalam kertas kerja ini, amplitud dan fasa dianggarkan secara serentak. Hasil simulasi menunjukkan kaedah yang dicadangkan mempunyai kelajuan penumpuan lebih pantas dengan nilai sebenar, prestasi yang lebih baik dan ketepatan yang lebih tinggi dalam sistem yang bising berbanding dengan algoritma rekursif kuasa dua terkecil pembolehubah faktor lupaan (RLSVFF). Ini menunjukkkan keunggulan kaedah yang dicadangkan.

KEYWORDS: Power system harmonic; BFO algorithm; SGVFF method; RLSVFF method 


\section{INTRODUCTION}

Nonlinear loads such as power-electronic devices, induced furnaces, computers, compact fluorescent lamp, etc. cause harmonics and disturbances in power systems. Some devices such as computers and UPSs are very sensitive to harmonics. The current and voltage of harmonics increase the power loss, transient voltages, transformers saturations and longevity of sensitive electronic devices. Unfavorable effects of harmonics in the network clarify the necessity of studying about harmonic involving modeling measuring and estimating amplitude and phase of harmonic components. Thus, use of an effective method is essential for measuring frequency in the presence of noise and high order harmonics. The effects of harmonics in power systems can be decreased by using harmonic filters and harmonic suppressors [1-3]. Before designing such filters, the amplitudes and phases of harmonics generated in power systems must be known. Thus, estimation of harmonics is an important problem in power systems.

A wide range of techniques applied in such problems is discussed: Estimating the phase angle and measuring bus voltage and high order harmonics in a noisy system using Kalman filter are explained in [4].These results are useful in studying harmonic distortions. In [5-7], a Kalman filter is applied for analysis of harmonics in power system. The Kalman filter introduces observation error equation by statistical investigation of signal for estimation and linearization. This is used for analysis of power systems with harmonics of order 5, 7, 11 and 13 and signal-to-noise ratio (SNR) of 400 with a Gaussian noise of 0.01 in ordinary condition and sudden changes of frequency. In [8-10], the Newton method is used for estimation of harmonics in power systems. However, large computational effort is a disadvantage of this method. In [11], the least square method (LS) is proposed for harmonic estimation. The method is proposed together with FFT methods and the Kalman Filter. Simulation methods verify that estimation of harmonic components using the LS method has many advantages with respect to other methods due to fewer required computations. In [12], three methods such as the Discrete Fourier transform (DFT), least absolute value (LAV) and least square (LS) method are used to estimate the harmonics. Among these methods, LAV leads to better results in harmonic estimation. In [13], the least mean square algorithm is presented for harmonic estimation in power systems. The weakness of this algorithm is in convergence speed. In [14], the adaptive linear neuron (ADALINE) method is used to estimate harmonics of time variant and time invariant signals.

In [15], estimation of harmonics is divided into two sections. First, amplitude is estimated using the LS method then phase component of harmonics is estimated by the ADALINE method. Fast convergence, short processing time and little computation are advantages of this method. In [16], stochastic gradient (SG) algorithm is explained. In [1720], properties of multi-innovation stochastic gradient (MISG) algorithm is described and the strength and weakness of the method are investigated. In [21], BFO algorithm is defined and in [22] a hybrid method called BFO-RLS algorithm is applied to estimate the amplitude and phase of power signal. The advantage of the mentioned method is the accuracy of the tracking error. In [23], estimation of harmonics that are integer multiplication of the principal frequency is performed using least square method and genetic algorithm. In [24], robust harmonic estimation of a time variable signal is investigated using RLSFF method. In $[25,26]$, RLS algorithm with variable forgetting factor is explained. The main problem in harmonic estimation is based on this fact that harmonic generating loads exist in power systems naturally and their amplitudes are also different. Thus, a method is required that needs fast measurement and accurate estimation of harmonic signals. Even though, estimation of higher order harmonics in time variable signals using RLSFF method involves few computations; it involves large initial estimation error and slow convergence; since 
harmonic estimation is a nonlinear problem and using linear optimization methods to solve such problems make the convergence speed slow, consequently we use a heuristic optimization method. Experimentation with several benchmark functions reveal that BFO possesses a good convergence speed and final accuracy[27-29] as compared to other naturally inspired optimization techniques like the genetic algorithm (GA) [30] particle swarm optimization (PSO) [31] and differential evolution (DE) [32].

Therefore, this paper uses BFO algorithm for initial estimation in an off-line stage on a few data smples. The BFO method is used to estimate unknown parameters based on minimization of a cost function, which is used as an initial value of the parameters for SGVFF. The SGVFF method is then applied on-line and recursively for reminded data.

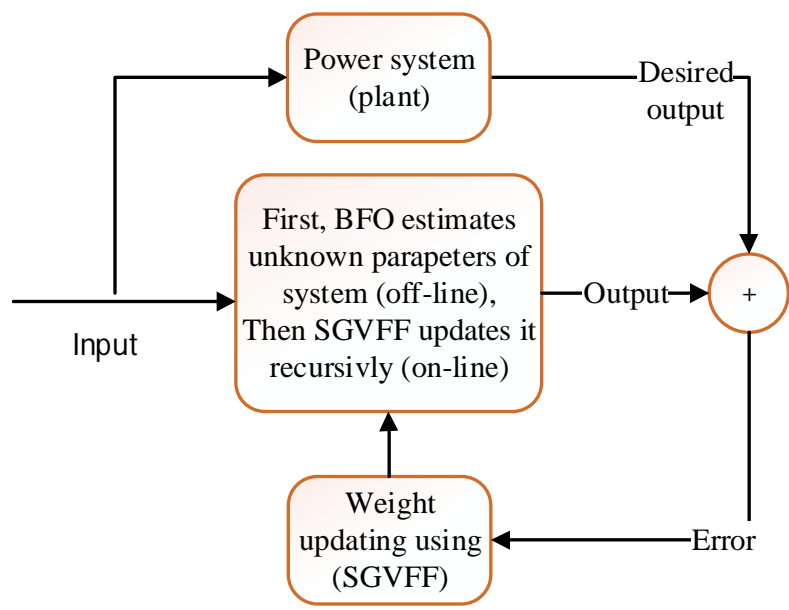

Fig. 1: Structure of SGVFF-BFO estimation scheme.

The proposed method enhances the performance and reduces overall convergence speed. Figure 1 shows the proposed estimation scheme of employing the BFO-SGVFF combined algorithm. First, a little input signal is fed to the BFO algorithm. Unknown parameters (weight vectors before initialization) are optimized using the BFO algorithm. Optimized output of BFO is taken as the initial values of weights for SGVFF. Then weights of SGVFF are updated using a recursive rule.In the applied hybrid method, the amplitudes and phases of the principal component of the harmonic is estimated from the output of SGVFF algorithm simultaneously.The rest of the paper is organized as follows:

In section 2, harmonic estimation of power systems is presented. In section 3, the BFO optimization algorithm is explained and in section 4, a description of the SGVFF algorithm is investigated. In section 5, RLSVFF and SGVFF algorithms are compared. In section 6, BFO-SGVFF hybrid algorithm is proposed for estimation of harmonics. In section 7 , simulation results are shown and conclusion is presented in section 8.

\section{HARMONIC ESTIMATION OF POWER SYSTEM}

First, it is assumed that the voltage and current waveform of the power system is with an angular frequency of $\omega$ as a principal and known harmonic and as a sum of harmonics with unknown amplitude and phase. The disturbed power signal is modeled as: 


$$
\mathrm{y}(\mathrm{t})=\sum_{n=1}^{N} a_{n} \sin \left(n \omega t+\varphi_{\mathrm{n}}\right)+v(t)
$$

where $N$ is the number of harmonics and $\omega=2 \pi f_{0}$ and $f_{0}$ is the principal frequency and $v(t)$ is an additive Gaussian white noise. If equation (1) is written in discrete form:

$$
\begin{aligned}
\mathrm{y}_{\mathrm{k}} & =\sum_{\mathrm{n}=1}^{\mathrm{N}} \mathrm{a}_{\mathrm{n}} \sin \left(\omega_{\mathrm{n}} \mathrm{kT}_{\mathrm{s}}+\varphi_{\mathrm{n}}\right)+v_{\mathrm{k}} \\
& \omega_{n}=n \omega: \text { Angular velocity } \\
& \varphi_{n}: \text { Phase of } \mathrm{n}^{\text {th }} \text { harmonic } \\
& a_{n}: \text { Amplitude of } \mathrm{n}^{\text {th }} \text { harmonic } \\
& T_{s}: \text { Sample time } \\
& v_{k}: \text { White Guassian noise with zero mean and variance of } \sigma_{v}^{2}
\end{aligned}
$$

Equation (2) can be written as a linear regression problem as follows:

$$
y(k)=\mathrm{x}^{T}(\mathrm{k}) \theta(k)
$$

Where:

$$
\begin{aligned}
& \mathrm{x}(\mathrm{k})=\left[\sin \left(\omega T_{S}\right), \cos \left(\omega T_{S}\right), \ldots, \sin \left(N \omega T_{S}\right), \cos \left(N \omega T_{S}\right)\right]^{\mathrm{T}} \\
& \theta(k)=\left[a_{1} \cos \left(\varphi_{1}\right), a_{1} \sin \left(\varphi_{1}\right), \ldots, a_{N} \cos \left(\varphi_{N}\right), a_{N} \sin \left(\varphi_{N}\right)\right]^{T}
\end{aligned}
$$

Where the regression $x(k)$ is a vector of known data and $\theta(k)$ is the vector of unknown parameters. $\theta(k)$ is achieved by solving an optimization problem (assuming $\theta=\theta(k)$ ) and then the amplitude parameter $\hat{a}_{n}$ and the phase parameter $\hat{\varphi}_{n}$ correspond with the nth harmonic are calculated as follow:

$$
\begin{aligned}
& \hat{a}_{n}=\sqrt{\theta_{2 n}^{2}+\theta_{2 n-1}^{2}} \\
& \widehat{\varphi}_{n}=\tan ^{-1}\left(\frac{\theta_{2 n}}{\theta_{2 n-1}}\right)
\end{aligned}
$$

where $n$ is the order of the harmonic.

\section{BACTERIAL FORAGING OPTIMIZATION METHOD}

In this section, a brief description of the BFO algorithm is presented [21, 22]. The concept of bacterial foraging optimization algorithm is based on the fact that in nature, animals with a low sense of foraging are more probably extinct in comparison with animals with high sense of foraging. Through many of generations, animals with low sense of foraging are extinct or transformed to better forms. The E. coli bacteria that lives in human 
intestines has a four-step foraging method. These steps are chemotactic, swarming, reproduction and elimination and dispersal (for detail see [21, 22]).

BFO algorithm can be described in the following steps:

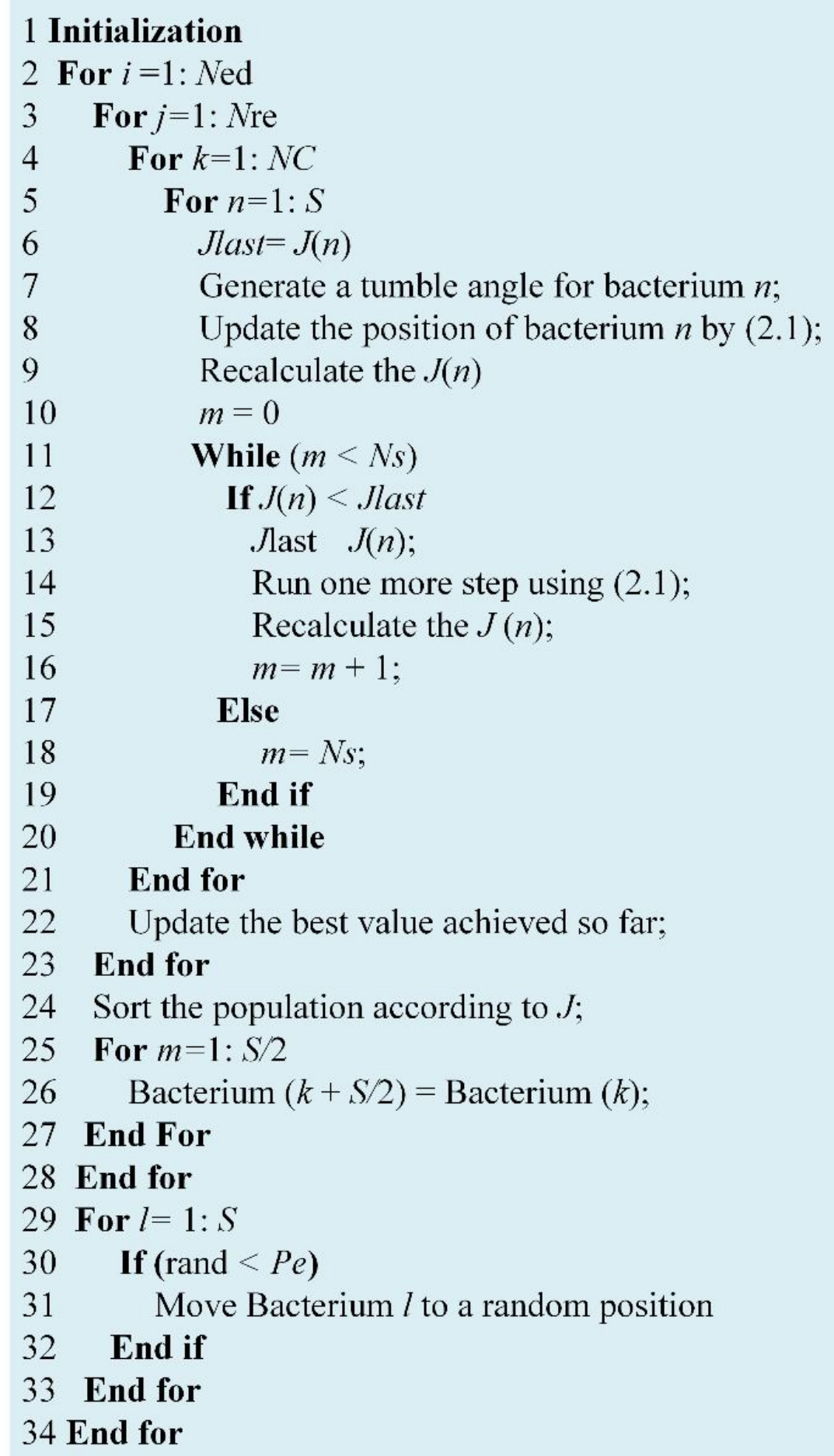




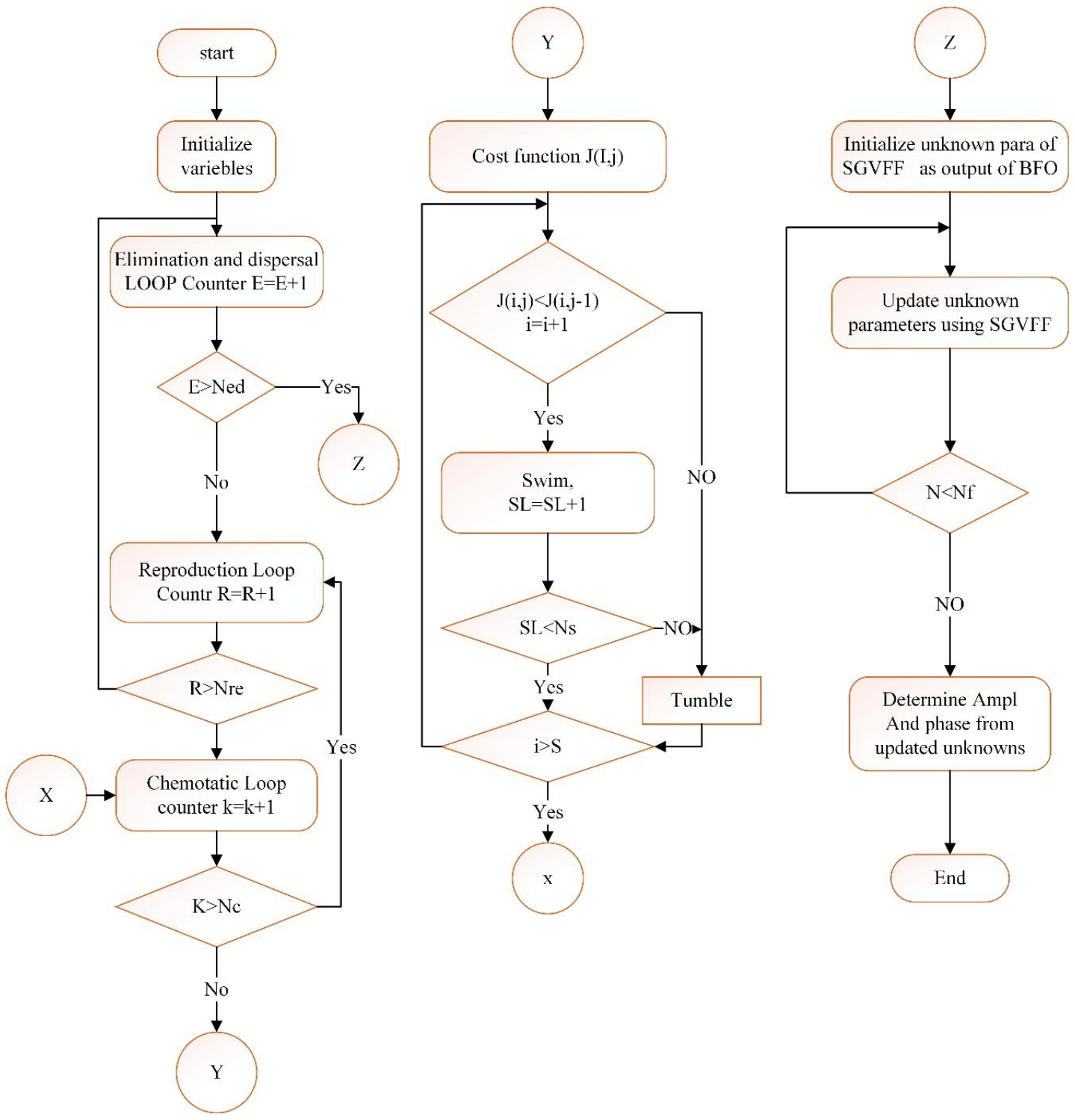

Fig. 2: Flow chart of BFO-SGVFF algorithm.

\section{DESCRIPTION OF ALGORITHM (SGVFF)}

Stochastic gradient algorithm with variable forgetting factor is widely used in signal processing and parameter estimation in adaptive control [16-20]. The advantages of this algorithm are fewer computations, fast estimation and high convergence in time variable systems. Consider the following linear regression model:

$$
y(k)=x^{T}(k) \theta+v(k)
$$

Where $y(k) \in R^{1}$ is the system output, $x^{T}(k) \in \mathrm{R}^{\mathrm{n}}$ is the system information vector (input, output), $v(k) \in R^{1}$ is a Gaussian white noise with zero mean and $\hat{\theta}$ is the estimation of $\theta$ at time k. Assume $y(k)=0, x(k)=0$ and $v(k)=0$ for $k \leq 0 .\{y(k), x(k)\}$ is the available measured information. For simplicity, it is assumed that $\mathrm{k}$ is the present time, thus $x(k)$ and $y(k)$ are the present information. Using stochastic gradient principal (SG), recursive $\mathrm{SG}$ identification algorithm is defined as follows: 


$$
\mathrm{e}(\mathrm{k})=\mathrm{y}(\mathrm{k})-x^{\mathrm{T}}(\mathrm{k}) \hat{\theta}(\mathrm{k}) \in \mathrm{R}^{1}
$$

Matrix $X(k)$ and output $y(k)$ is as follow:

$$
\begin{aligned}
& X(k)=[x(k), x(k-1), . ., x(k-p+1)] \in R^{n} \\
& Y(k)=[y(k), y(k-1), ., y(k-p+1)]^{T} \in R^{1}
\end{aligned}
$$

Stochastic gradient algorithm is defined as follows [26]:

$$
\begin{aligned}
& \hat{\theta}(\mathrm{k})=\hat{\theta}(\mathrm{k}-1)+\frac{X(\mathrm{k})}{\mathrm{r}(\mathrm{k})} \mathrm{e}(\mathrm{k}) \\
& \mathrm{e}(\mathrm{k})=\mathrm{y}(\mathrm{k})-\mathrm{x}^{\mathrm{T}}(\mathrm{k}) \hat{\theta}(\mathrm{k}-1) \\
& \mathrm{r}(\mathrm{k})=\lambda \mathrm{r}(\mathrm{k}-1)+\|x(\mathrm{k})\|^{\mathrm{T}}, r(0)>0 \\
& \lambda=\lambda_{\text {min }}+\left(1-\lambda_{\text {min }}\right) \times \log \operatorname{sig}(k / M)
\end{aligned}
$$

Where $\lambda$ is the forgetting factor and is defined as a variable, $M$ is an arbitrary constant value.

\begin{tabular}{|c|c|}
\hline System & SISO system \\
\hline initial value & $\begin{array}{l}y(k)=x^{T}(k) \theta+v(k) \\
y(k) \in \mathrm{R}^{1}, \quad x^{T}(k) \in \mathrm{R}^{\mathrm{n}} \\
v(k) \in \mathrm{R}^{1}, \theta \in \mathrm{R}^{\mathrm{n}}\end{array}$ \\
\hline RLSVFF algorithm & $\begin{array}{l}\text { procedure of the algorithm from equation }(17-20) \\
\text { parameter estimation vector } \hat{\theta}(\mathrm{k}) \in \mathrm{R}^{\mathrm{n}} \text { : } \\
\text { gain vector: } \mathrm{L}(\mathrm{k})=\mathrm{P}(\mathrm{k}) x(k) \in \mathrm{R}^{\mathrm{n}} \\
\text { error vector: } \mathrm{e}(\mathrm{k})=\mathrm{y}(\mathrm{k})-x^{\mathrm{T}}(\mathrm{k}-1) \hat{\theta}(\mathrm{k}) \in \mathrm{R}^{1} \\
\text { covariance matrix: } \mathrm{P}(\mathrm{k}) \in \mathrm{R}^{\mathrm{n} \times \mathrm{n}}\end{array}$ \\
\hline SGVFF algorithm & $\begin{array}{l}\text { procedure of the algorithm from equation }(9-14) \\
\text { gain vector: } \mathrm{L}(\mathrm{k})=\frac{X(\mathrm{k})}{\mathrm{r}(\mathrm{k})} \in \mathrm{R}^{\mathrm{n}} \\
\text { error vector: } \mathrm{e}(\mathrm{k})=\mathrm{y}(\mathrm{k})-x^{\mathrm{T}}(\mathrm{k}-) \hat{\theta}(\mathrm{k}) \in \mathrm{R}^{1} \\
\text { variable forgetting factor: } \lambda=\lambda_{\text {min }}+\left(1-\lambda_{\text {min }}\right) \times \log \operatorname{sig}(\mathrm{k} / \mathrm{m})\end{array}$ \\
\hline
\end{tabular}

$$
\begin{aligned}
& x(\mathrm{k})=[x(\mathrm{k}), x(\mathrm{k}-1), \ldots, x(\mathrm{k}+1)] \in \mathrm{R}^{\mathrm{n}} \\
& y(k)=[y(k), y(k-1), \ldots, y(k+1)]^{T} \in R^{1}
\end{aligned}
$$

\section{COMPARISON OF RLSVFF AND SGVFF ALGORITHM}

In this section comparison of SGVFF and RLSVFF algorithms is shown in Table 1.

Table 1: comparison of SGVFF and RLSVFF algorithms 


\section{HYBRID CONFIGURATION OF THE PROPOSED BFO-SGVFF ALGORITHM FOR HARMONIC ESTIMATION}

The flowchart of the proposed harmonic estimation method is briefly shown in Fig. 1 and is briefly illustrated in Fig. 2. In this method, an initial signal with limited information is first introduced to BFO algorithm and unknown parameter namely $\widehat{\theta}$ is estimated by this method.Optimal output of BFO algorithm is considered as an initial value of the unknown parameter namely $\hat{\theta}(0)$ in SGFF algorithm. Then the updated $\hat{\theta}(k)$ is used through the procedure of SGFF algorithm. Also, estimation of harmonic component namely amplitude of $\hat{a}$ based on updated $\hat{\theta}(k)$ is obtained from the output of SGVFF algorithm according to some equations. Using mentioned hybrid configuration is due to this fact that in estimation by SGVFF method the convergence trend is highly sensitive to the initial guess. As a result, first by applying little and limited information through an Off-line procedure using BFO algorithm, initial value of the parameters for SGVFF algorithm is obtained and after calculation of this estimation, SGVFF is applied in an On-line procedure.

\section{SIMULATION}

In this section, a power signal with time variable amplitude is considered for high, third and fifth order harmonic estimation.

$$
\begin{gathered}
y(k)=\left(1.5+b_{1}(k)\right) \sin \left(k \omega T_{s}+\frac{\pi}{6}\right)+\left(0.5+b_{3}(k)\right) \sin \left(3 k \omega T s+\frac{\pi}{3}\right) \\
+\left(0.2+b_{5}(k)\right) \sin \left(5 k \omega T s+\frac{\pi}{4}\right)+v(k)
\end{gathered}
$$

Where

$$
\begin{aligned}
& b_{1}(k)=0.15 \sin 2 \pi f_{1} k T_{s}+0.05 \sin 2 \pi f_{5} k T_{s} \\
& b_{3}(k)=0.05 \sin 2 \pi f_{3} k T_{s}+0.02 \sin 2 \pi f_{5} k T_{s} \\
& b_{5}(k)=0.025 \sin 2 \pi f_{1} k T_{s}+0.005 \sin 2 \pi f_{5} k T_{s}
\end{aligned}
$$

and $v(k)$ is a white Gaussian noise with variance $=0.1$.

Equation (4) is rewritten for estimating the amplitude and phase:

$$
y(k)=\mathrm{x}^{T}(\mathrm{k}) \theta(k)
$$

Then, signal is transformed to a parametric form:

$$
\begin{aligned}
& x(k)=\left[\sin \left(k \omega T_{s}\right) \cos \left(k \omega T_{s}\right)\right. \\
& \sin \left(3 k \omega T_{s}\right) \cos \left(3 k \omega T_{s}\right) \\
& \left.\sin \left(5 k \omega T_{s}\right) \cos \left(5 k \omega T_{s}\right)\right]^{T}
\end{aligned}
$$

Also, 


$$
\theta(\mathrm{k})=\left[\begin{array}{l}
a_{1} \cos \left(\varphi_{1}\right) \\
a_{1} \sin \left(\varphi_{1}\right) \\
a_{3} \cos \left(\varphi_{3}\right) \\
a_{3} \sin \left(\varphi_{3}\right) \\
a_{5} \cos \left(\varphi_{5}\right) \\
a_{5} \sin \left(\varphi_{5}\right)
\end{array}\right]
$$

where the vector of signal parameters is achieved as follows:

$$
\theta(\mathrm{k})=\left[\begin{array}{c}
\left(1.5+b_{1}(k)\right) \cos \varphi_{1} \\
\left(1.5+b_{1}(k)\right) \sin \varphi_{1} \\
\left(0.5+b_{3}(k)\right) \cos \varphi_{3} \\
\left(1.5+b_{3}(k)\right) \sin \varphi_{3} \\
\left(0.2+b_{5}(k)\right) \cos \varphi_{5} \\
\left(0.2+b_{5}(k)\right) \sin \varphi_{5}
\end{array}\right]
$$

By assuming $\theta=\theta(k) \in R^{6}$ and after updating unknown parameters, the main amplitude and phase and the third and the fifth harmonic is achieved as follows:

$$
\begin{aligned}
& \hat{a}_{1}=\sqrt{\theta_{1}^{2}+\theta_{2}^{2}} \\
& \hat{a}_{3}=\sqrt{\theta_{3}^{2}+\theta_{4}^{2}} \\
& \hat{a}_{5}=\sqrt{\theta_{5}^{2}+\theta_{6}^{2}} \\
& \widehat{\varphi}_{1}=\tan ^{-1}\left(\frac{\theta_{2}}{\theta_{1}}\right) \\
& \widehat{\varphi}_{3}=\tan ^{-1}\left(\frac{\theta_{4}}{\theta_{3}}\right) \\
& \widehat{\varphi}_{5}=\tan ^{-1}\left(\frac{\theta_{6}}{\theta_{5}}\right)
\end{aligned}
$$

where $\hat{a}_{1}, \hat{a}_{3}, \hat{a}_{5}$ and $\hat{\varphi}_{1}, \hat{\varphi}_{3}, \hat{\varphi}_{5}$ are the amplitudes and the phases estimation parameters respectively.

As is described in section5, first by BFO algorithm and considering little information (here only first twenty samples of signal) initial estimation of the unknown parameters is achieved, then SGVFF algorithm with variable forgetting factor is applied. Meanwhile, $\lambda_{\min }=0.2, M=100$ and $k=500$. The principal power signal following with the estimated and reconstructed power signal by the proposed and RLSVFF methods are depicted in Fig. 3.

Estimation of parameters $a_{1}, a_{3}$ and $a_{5}$ which are the amplitudes of the first, third and fifth harmonic respectively are depicted in Fig.4, Fig. 5 and Fig. 6. Also, estimation of parameters $\varphi_{1}, \varphi_{3}$ and $\varphi_{5}$ which are the phases of the first, the third and the fifth harmonic 
respectively are depicted in Fig. 7, Fig. 8 and Fig. 9. As can be seen from these figures, the proposed method provides better performance by appropriate initial estimation and then by fast convergence in comparison with the RLSVFF method.

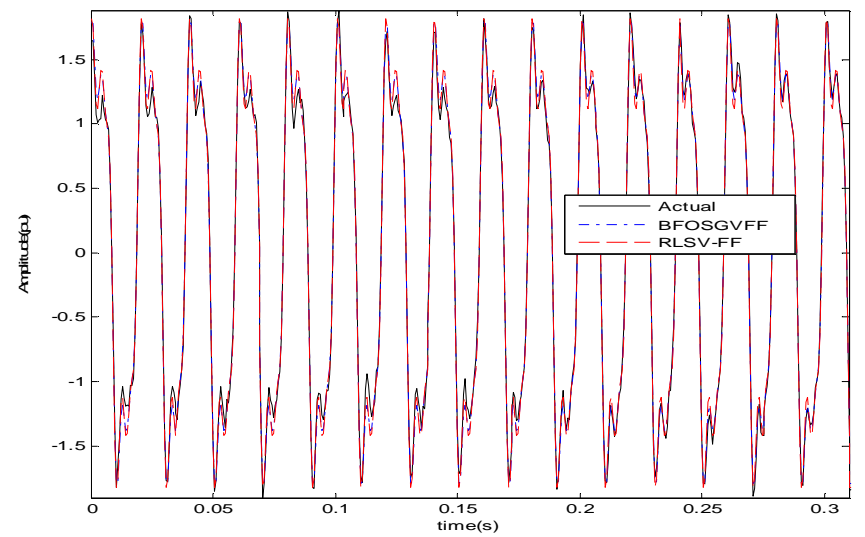

Fig. 3: Estimation of reference signal.

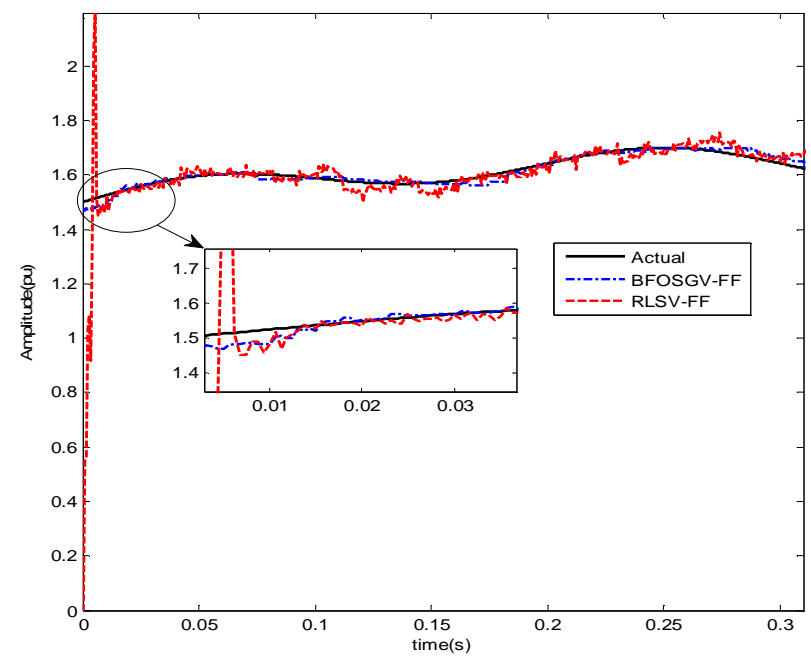

Fig. 4: Amplitude estimation of the first harmonic.

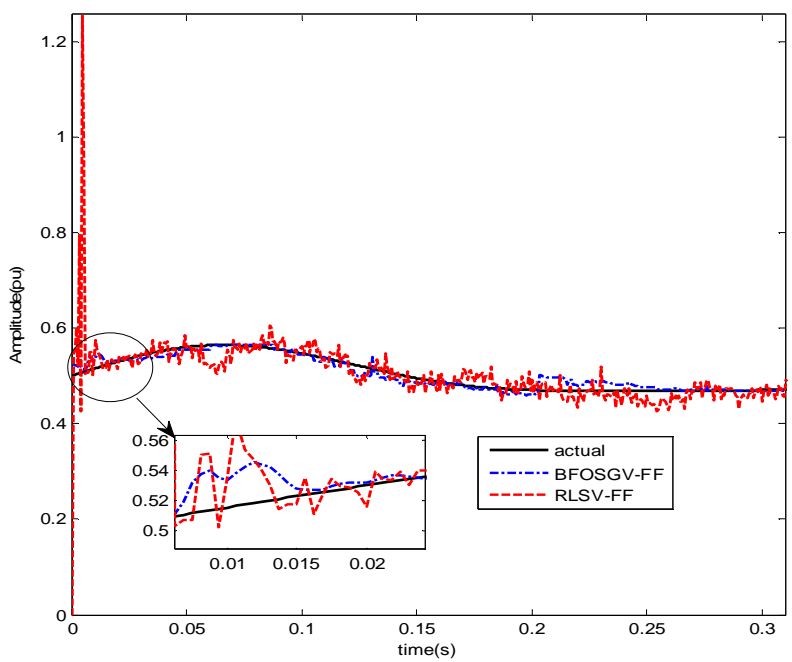

Fig. 5: Amplitude Estimation of the third harmonic. 


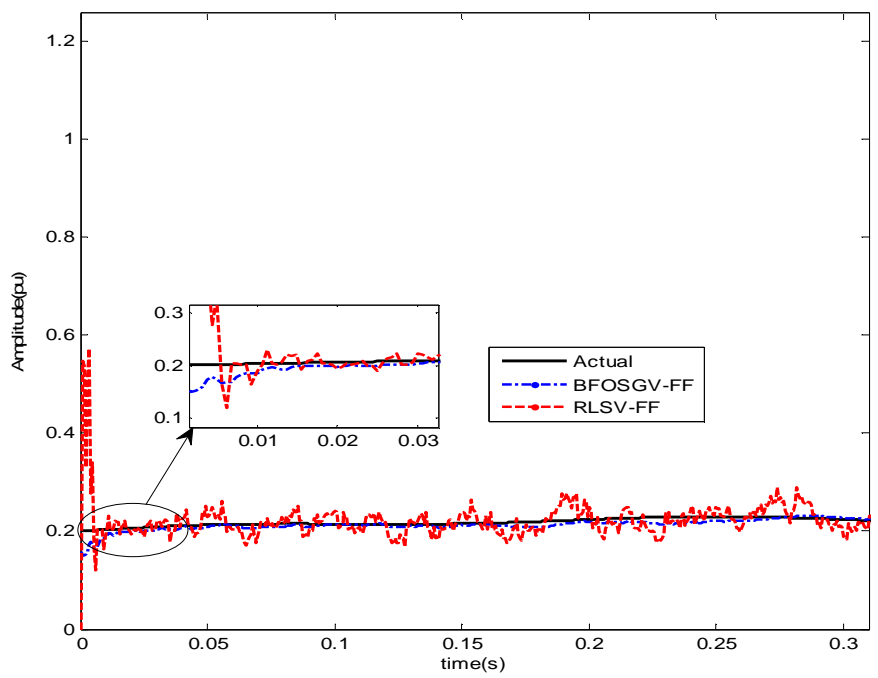

Fig. 6: Amplitude estimation of the fifth harmonic.

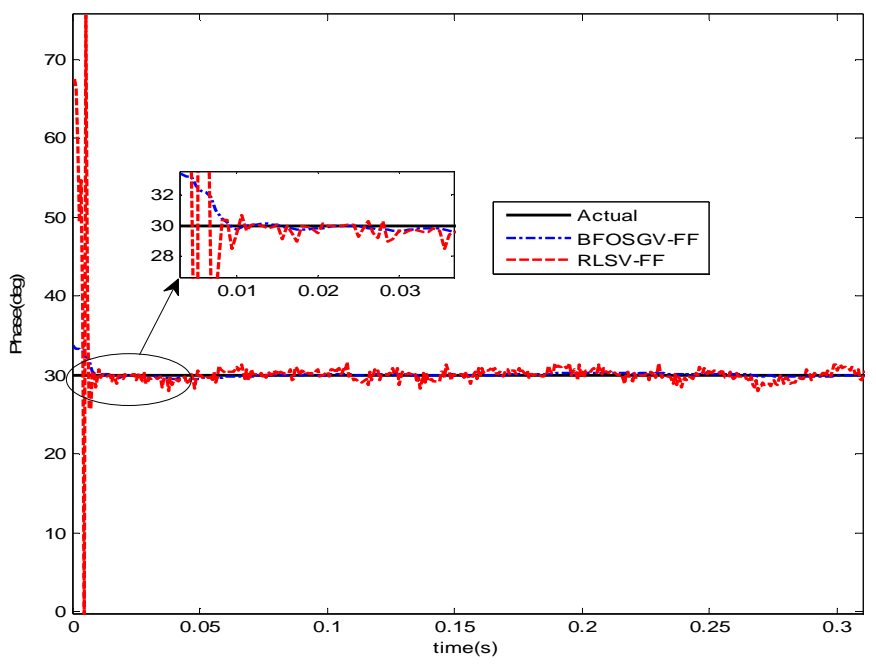

Fig. 7: Phase estimation of the first harmonic.

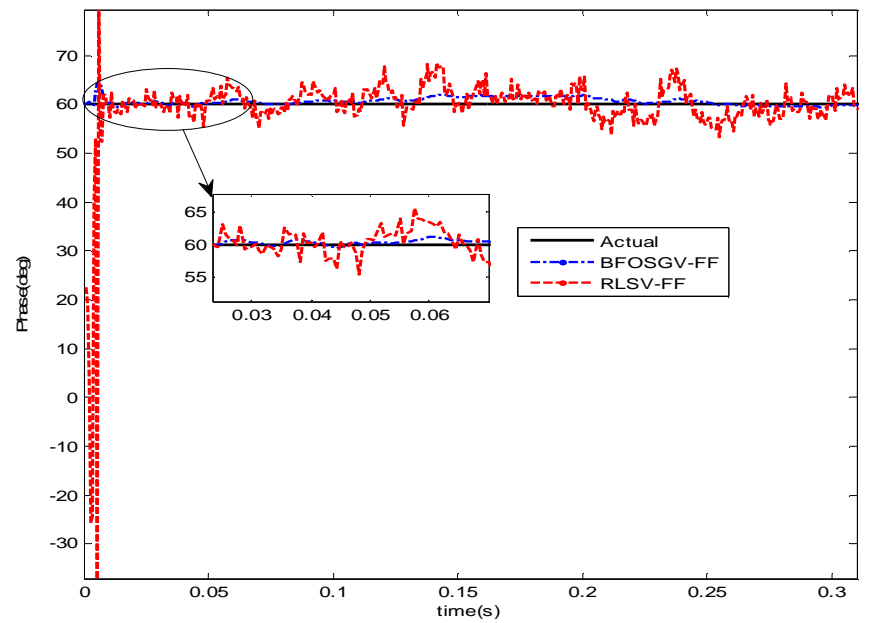

Fig. 8: Phase estimation of the third harmonic. 


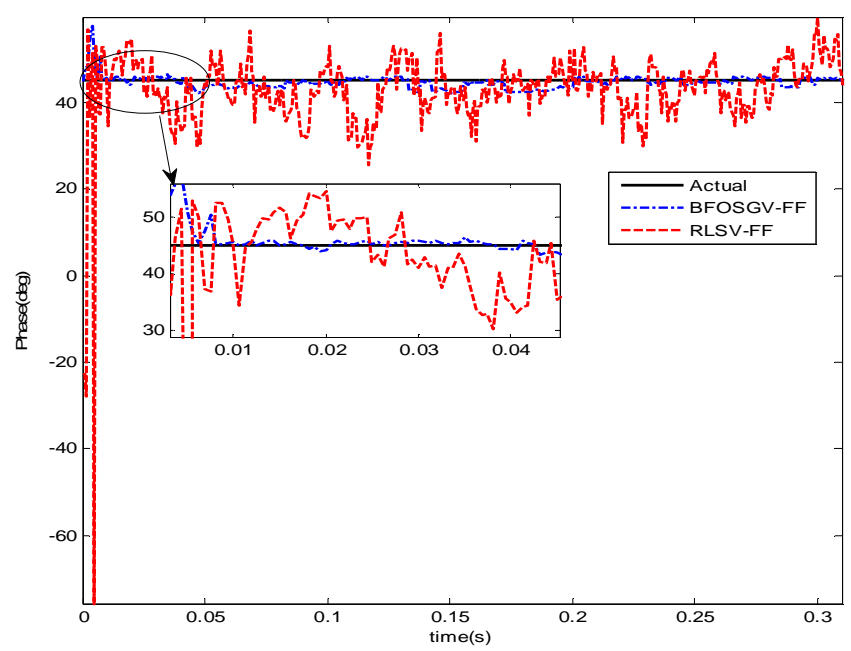

Fig. 9: Phase estimation of the fifth harmonic.

To show the performance of the proposed method, four criteria are used. These are the mean square value of the error (MSE or variance), mean absolute value of the error (MAE), error in percentage, and standard deviation. In equations (29) to (32), $y(k)$ is the reference signal and $\hat{y}(k)$ is the estimated signal for $\mathrm{k}^{\text {th }}$ sample that are used for comparison of the wave form achieved from applying BFO-SGVFF and RLSVFF methods on the components of power system harmonics

The mean square value of error (MSE):

$$
M S E=\frac{1}{N} \sum_{K=1}^{N}[y(k)-\hat{y}(k)]^{2}
$$

The mean absolute value of the error (MAE)

$$
M A E=\frac{1}{N} \sum_{K=1}^{n}|y(k)-\hat{y}(k)|
$$

Error in percentage:

$$
\text { \%error }=\frac{1}{N} \sum_{k=1}^{n}\left([y(k)-\hat{y}(k)]^{2} /(y(k))^{2}\right) \times 100
$$

Standard deviation:

$$
\sigma=\sqrt{\frac{1}{N} \sum_{K=1}^{N}[y(k)-\hat{y}(k)]^{2}}
$$

The results achieved from the above methods were presented in Tables 2-5. The simulation results achieved for MSE criteria were shown in Table 2. Table 3 is correspondent with MAE criteria, Table 4 is correspondent with the criteria of error in 
percentage and finally Table 5 shows the standard deviation. These tables show that the proposed method in all four mentioned criteria is better than RLSVFF. Also, Fig. 10 and Fig. 11 correspond with the comparison between the proposed method and RLSVFF method in terms of harmonic amplitudes and phases. Figures 12 and 13 correspond with MAE criteria of the amplitude and phase. Figures 14 and 15 are the error percentage of the amplitude and phase of the power system harmonic. Figures 16 and 17 show the standard deviation of amplitude and phase estimation. The achieved results denote that the results of the proposed method are closer to the reference signal and is more applicable in comparison to RLSVFF method. In addition, the convergence speed in our proposed method is faster than RLSVFF method.

Table 2: Comparison of the (MSE) of BFO-SGVFF with RLSVFF

\begin{tabular}{cccc|ccc}
\hline \multirow{2}{*}{ Method } & \multicolumn{3}{c|}{ Amplitude } & \multicolumn{3}{c}{ Phase } \\
\cline { 2 - 7 } & $\begin{array}{c}1^{\text {st }} \\
\text { harmonic }\end{array}$ & $\begin{array}{c}3^{\text {rd }} \\
\text { harmonic }\end{array}$ & $\begin{array}{c}5^{\text {th }} \\
\text { harmonic }\end{array}$ & $\begin{array}{c}1^{\text {st }} \\
\text { harmonic }\end{array}$ & $\begin{array}{c}3^{\text {rd }} \\
\text { harmonic }\end{array}$ & $\begin{array}{c}5^{\text {th }} \\
\text { harmonic }\end{array}$ \\
\hline BFO-SGVFF & 0.0003 & 0.0002 & 0.0001 & 0.0273 & 0.156 & 7.414 \\
RLSVFF & 0.0094 & 0.0014 & 0.0012 & 12.155 & 90.645 & 59.404 \\
\hline
\end{tabular}

Table 3: Comparison of the (MAE) of BFO-SGVFF with RLSVFF

\begin{tabular}{cccc|ccc}
\hline \multirow{2}{*}{ Method } & \multicolumn{3}{c|}{ amplitude } & \multicolumn{3}{c}{ phase } \\
\cline { 2 - 6 } & $\begin{array}{c}1^{\text {st }} \\
\text { harmonic }\end{array}$ & $\begin{array}{c}3^{\text {rd }} \\
\text { harmonic }\end{array}$ & $\begin{array}{c}5^{\text {th }} \\
\text { harmonic }\end{array}$ & $\begin{array}{c}1^{\text {st }} \\
\text { harmonic }\end{array}$ & $\begin{array}{c}3^{\text {rd }} \\
\text { harmonic }\end{array}$ & $\begin{array}{c}5^{\text {th }} \\
\text { harmonic }\end{array}$ \\
\hline BFO-SGVFF & 0.0275 & 0.0223 & 0.117 & 0.2037 & 0.5608 & 1.0446 \\
RLSVFF & 0.428 & 0.355 & 0.323 & 1.514 & 4.808 & 8.194 \\
\hline
\end{tabular}

Table 4: Comparison of the (\%error) of BFO-SGVFF with RLSVFF

\begin{tabular}{cccc|ccc}
\hline \multirow{2}{*}{ Method } & \multicolumn{3}{c|}{ Amplitude } & \multicolumn{3}{c}{ Phase } \\
\cline { 2 - 6 } & $\begin{array}{c}1^{\text {st }} \\
\text { harmonic }\end{array}$ & $\begin{array}{c}3^{\text {rd }} \\
\text { harmonic }\end{array}$ & $\begin{array}{c}5^{\text {th }} \\
\text { harmonic }\end{array}$ & $\begin{array}{c}1^{\text {st }} \\
\text { harmonic }\end{array}$ & $\begin{array}{c}3^{\text {rd }} \\
\text { harmonic }\end{array}$ & $\begin{array}{c}5^{\text {th }} \\
\text { harmonic }\end{array}$ \\
\hline BFO-SGVFF & $1.963 \times 10^{-4}$ & $\begin{array}{c}1.133 \times 10^{-} \\
4\end{array}$ & $7.4417 \times 10^{-5}$ & $9.27 \times 10^{-4}$ & $1.53 \times 10^{-2}$ & $4.46 \times 10^{-3}$ \\
RLSVFF & $1.43 \times 10^{-2}$ & $5.36 \times 10^{-3}$ & $5.63 \times 10^{-4}$ & 2.73 & 15.67 & 27.68 \\
\hline
\end{tabular}

Table 5: Comparison of thestandard deviation $(\sigma)$ of BFO-SGVFF with RLSVFF

\begin{tabular}{cccc|ccc}
\hline \multirow{2}{*}{ Method } & \multicolumn{3}{c|}{ Amplitude } & \multicolumn{3}{c}{ Phase } \\
\cline { 2 - 6 } & $\begin{array}{c}1^{\text {st }} \\
\text { harmonic }\end{array}$ & $\begin{array}{c}3^{\text {rd }} \\
\text { harmonic }\end{array}$ & $\begin{array}{c}5^{\text {th }} \\
\text { harmonic }\end{array}$ & $\begin{array}{c}1^{\text {st }} \\
\text { harmonic }\end{array}$ & $\begin{array}{c}3^{\text {rd }} \\
\text { harmonic }\end{array}$ & $\begin{array}{c}5^{\text {th }} \\
\text { harmonic }\end{array}$ \\
\hline BFO-SGVFF & 0.0037 & 0.0031 & 0.0085 & 0.239 & 0.9737 & 5.443 \\
RLSVFF & 0.3066 & 0.0488 & 0.449 & 3.8313 & 8.985 & 11.093 \\
\hline
\end{tabular}



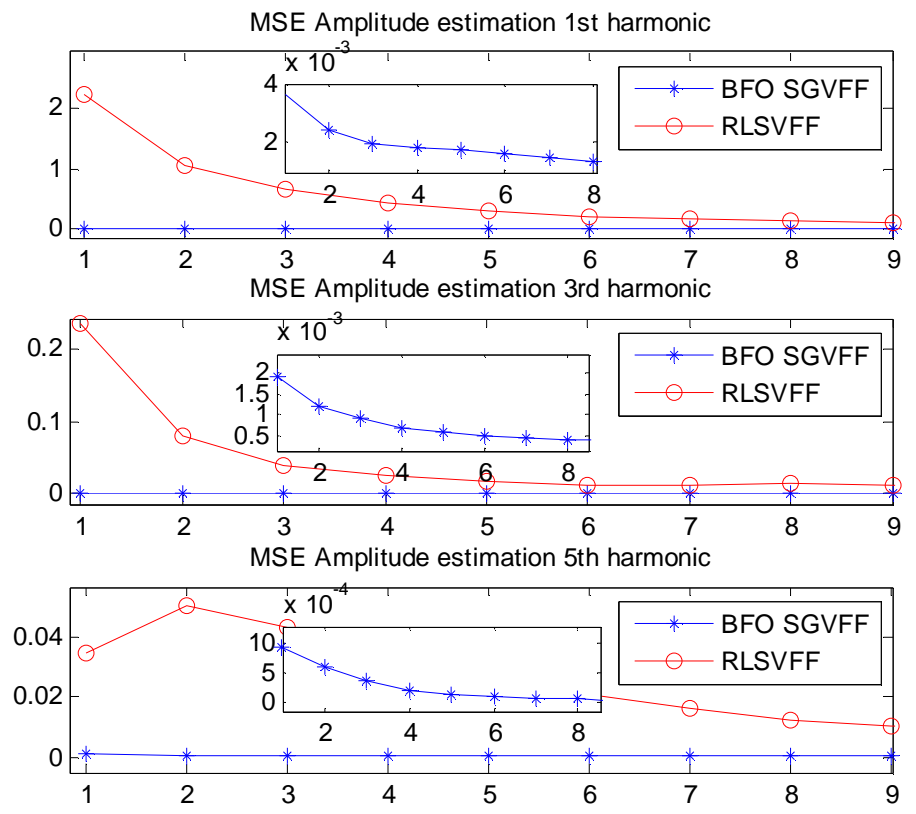

Fig. 10: MSE of amplitude harmonic estimation.
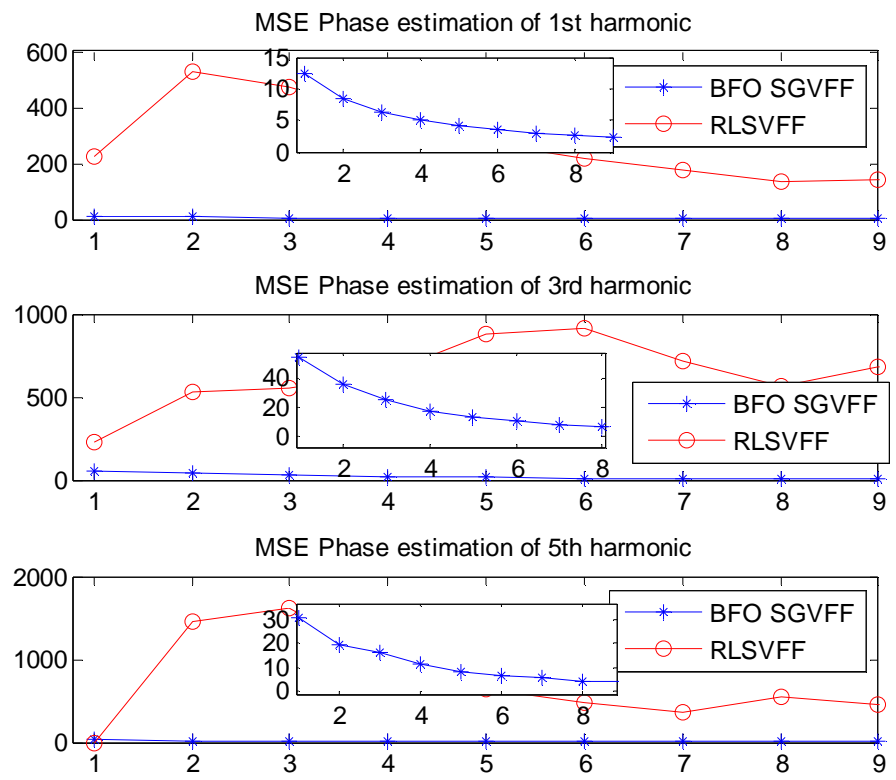

Fig. 11: MSE of phase harmonic estimation. 

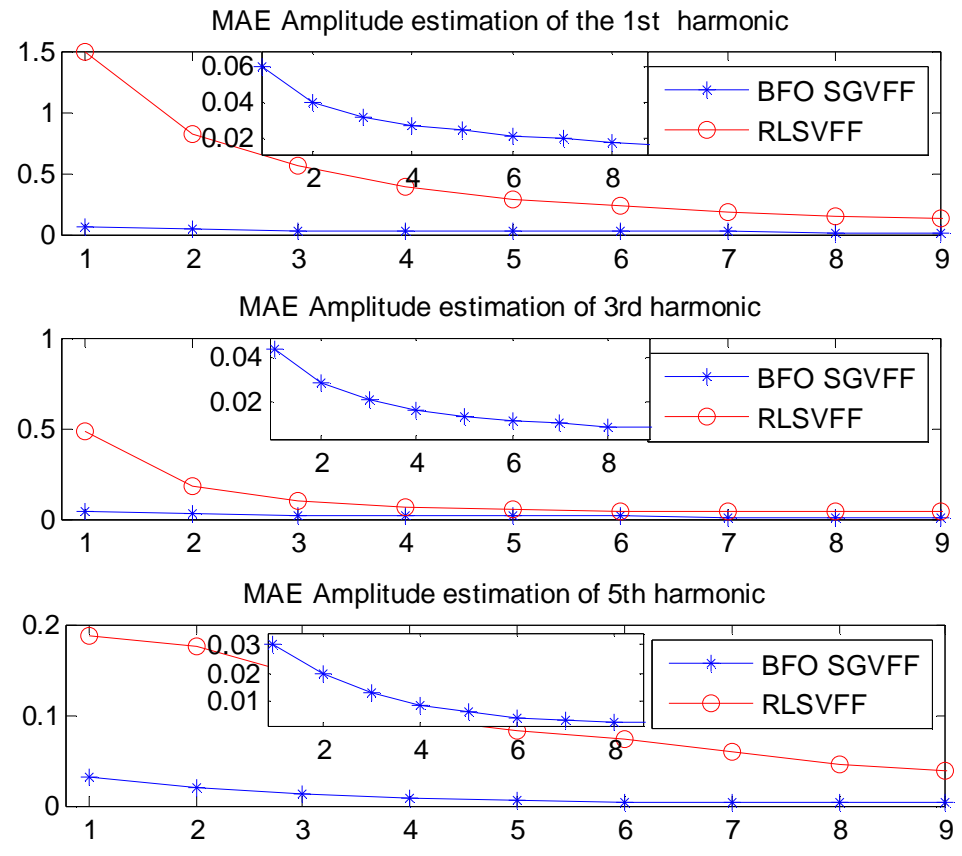

Fig. 12: MAE of amplitude harmonic estimation.
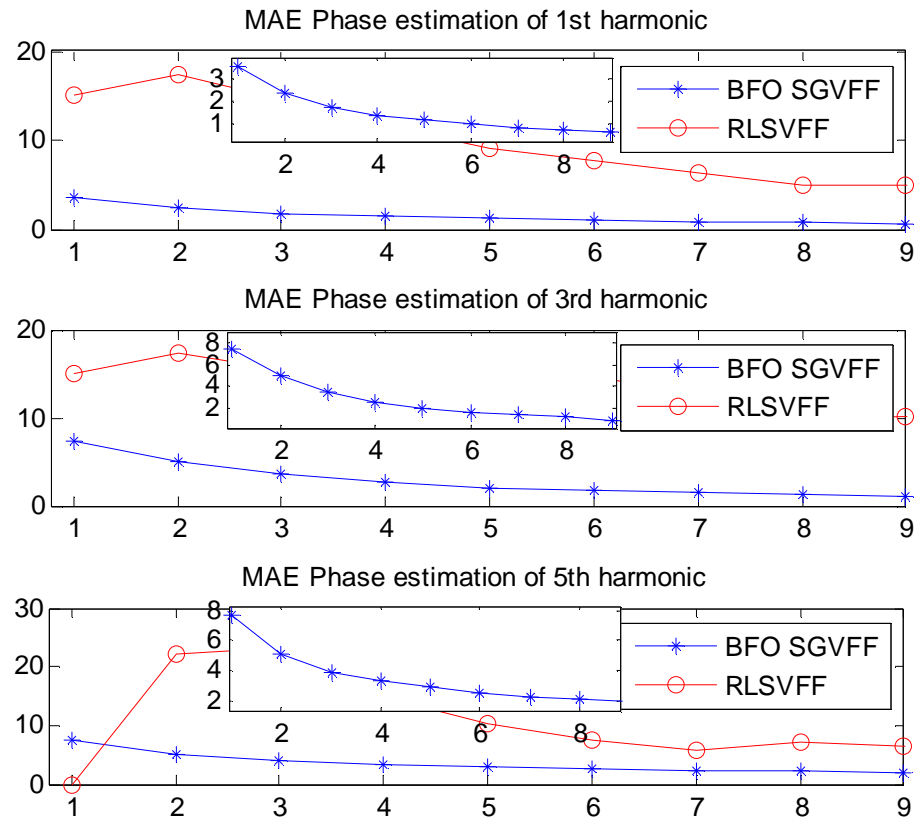

Fig. 13: MAE of phase harmonic estimation. 

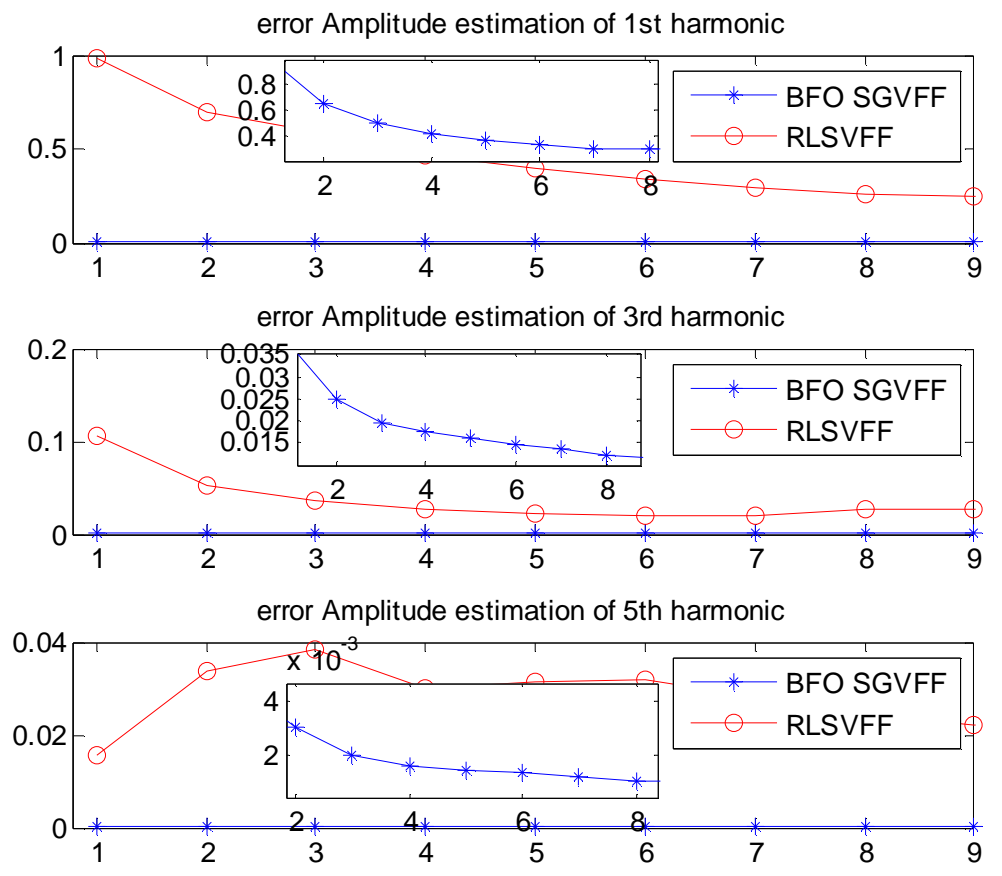

Fig. 14: \% Error of amplitude harmonic estimation.

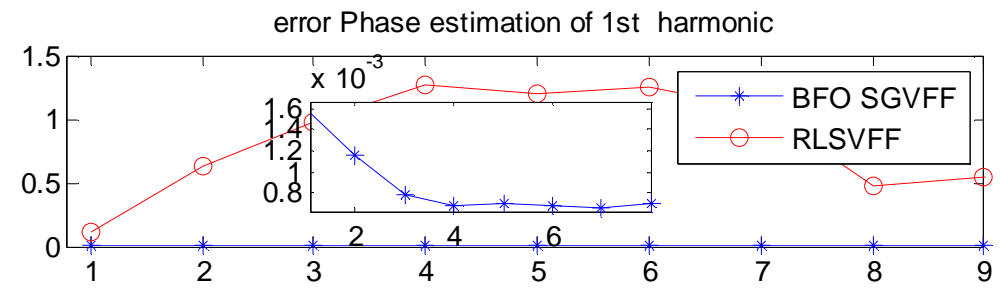

error Phase estimation of 3rd harmonic

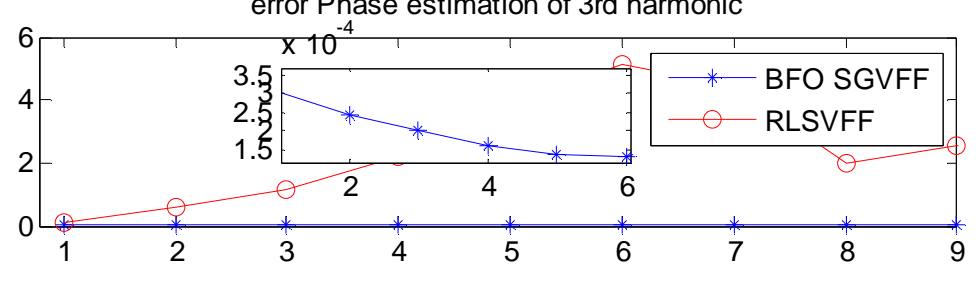

error Phase estimation of 5th harmonic

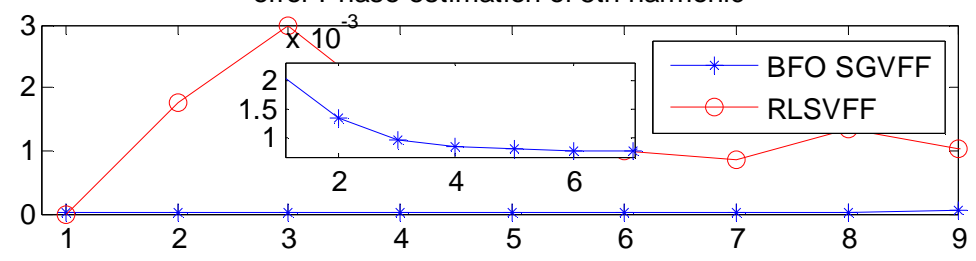

Fig. 15: \% Error of phase harmonic estimation. 


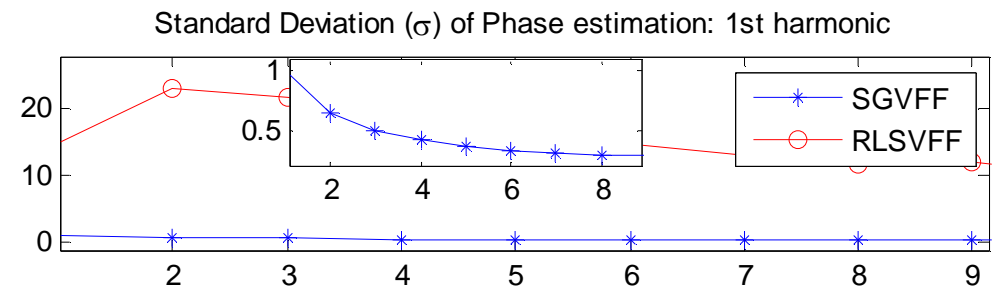

Standard Deviation $(\sigma)$ of Phase estimation: 3rd harmonic

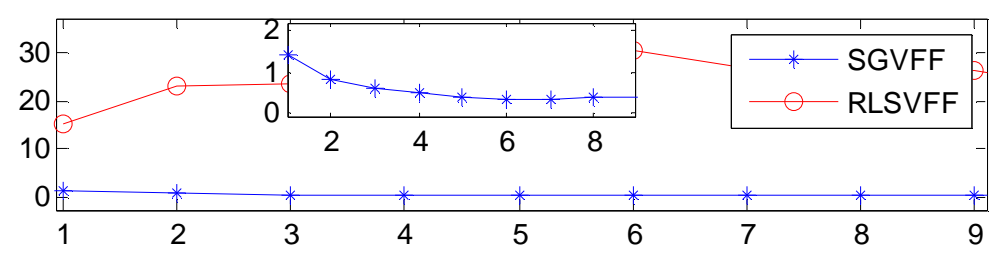

Standard Deviation $(\sigma)$ of Phase estimation: 5th harmonic

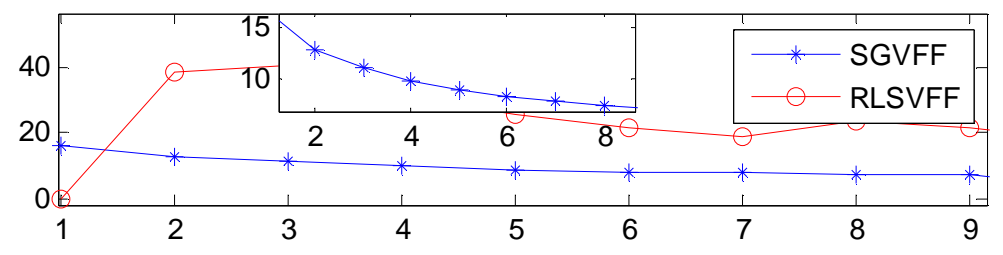

Fig. 16: Standard deviation ( $\sigma$ )of amplitude estimation.

Standard Deviation $(\sigma)$ of Amplitude estimation: 1st harmonic
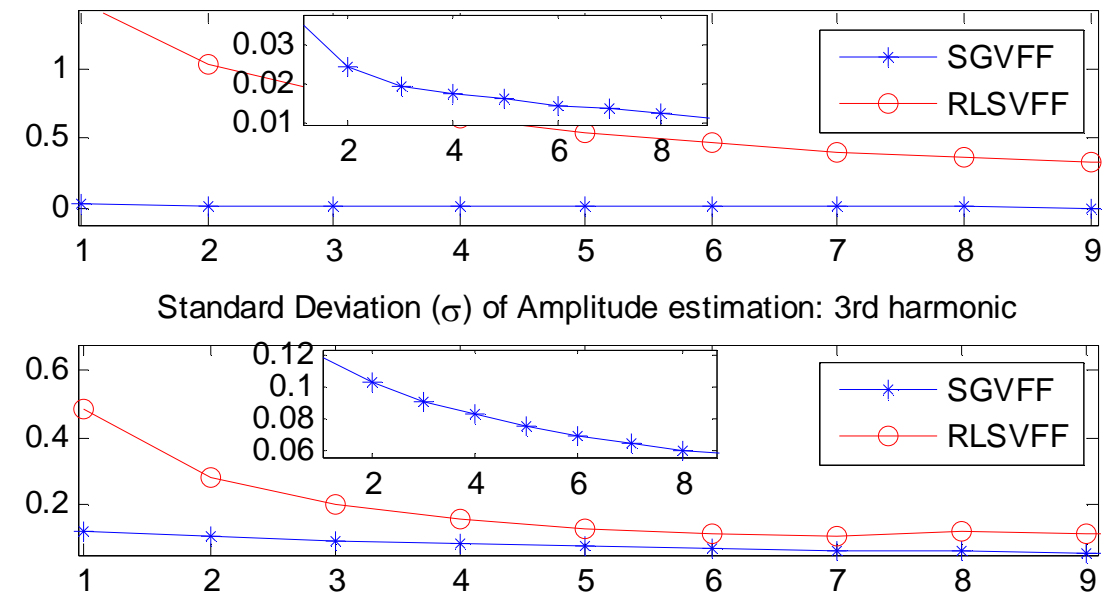

Standard Deviation $(\sigma)$ of Amplitude estimation: 5th harmonic

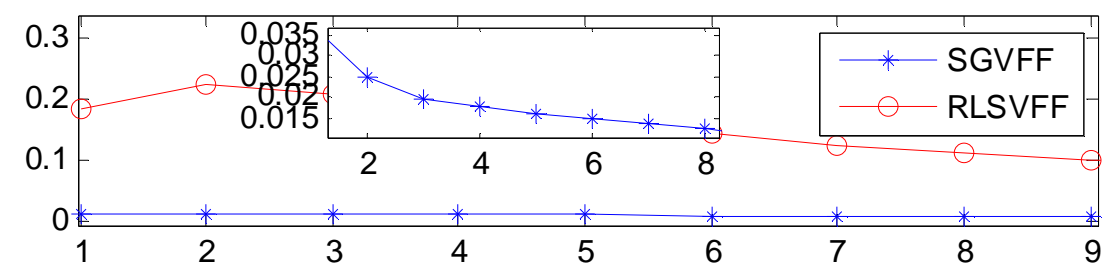

Fig. 17: Standard deviation $(\sigma)$ of phase estimation. 


\section{CONCLUSION}

The main problem in harmonic estimation is due to the existence of harmonic loads in power systems and the amplitude of produced harmonics being different from one another. Thus, a method is required that can measure and estimate harmonic signals as fast as possible. In this paper, a hybrid intelligent algorithm BFO-SGVFF is proposed for the first time to estimate amplitudes and phases of the harmonic simultaneously in a noisy power system signal. Enhancing the performance, the technique of variable forgetting factor is used. Using this technique is more effective according to the time variability of the reference signal. The proposed hybrid algorithm is used since in estimation by recursive methods such as RLSVFF, the convergence trend is highly dependent to the initial guess of the solution. Thus in the proposed method, the initial value of the parameters for SGVFF algorithm is achieved by first using little and limited information through an Off-line procedure using the BFO algorithm. After this initial estimation, SGVFF algorithm is applied in an On-line procedure. In fact, the output of BFO algorithm is used as an initial guess of the parameters in SGVFF algorithm. The simulation results verify superior performance of this algorithm in comparison with RLSVFF algorithm.

\section{REFERENCES}

[1] Tang, Y., Loh, P. C., Wang, P., Choo, F. H., Gao, F., \& Blaabjerg, F. (2012) Generalized design of high performance shunt active power filter with output LCL filter. Industrial Electronics, IEEE Transactions, 59(3):1443-1452.

[2] Bai, Z., Ma, H., Xu, D., Wu, B., Fang, Y., \& Yao, Y. (2014) Resonance damping and harmonic suppression for grid-connected current-source converter. Industrial Electronics, IEEE Transactions, 61(7):3146-3154.

[3] Hinduja, M., Rathi, M., Jaya Christa, S. T., \& Prabha, N. R. (2015) PI control of multi-level inverter based shunt active power filter for harmonic mitigation in three phase systems. Circuit, Power and Computing Technologies (ICCPCT), International Conference on IEEE.

[4] Beides HM, Heydt GT. (1991) Dynamic state estimation of power system harmonics using Kalman filter methodology. IEEE Transactions on Power Delivery, 6(4):1663-1670.

[5] Kennedy K, Lightbody G, Yacamini R. (2003) Power system harmonic analysis using the Kalman filter. IEEE Power Engineering Society General Meeting, 2:752-757.

[6] Routray A, Pradhan AK, Rao KP. (2002) A novel Kalman filter for frequency estimation of distorted signals in power system," IEEE Trans. Instrum. Meas., 51(3):469-479.

[7] Costa, F. F., Cardoso, A. J. M., \& Fernandes, D. A. (2007). Harmonic analysis based on Kalman filtering and Prony's method. In Power Engineering, Energy and Electrical Drives, 2007. POWERENG 2007. International Conference on (pp. 696-701). IEEE.

[8] Yang J, Xi H, Guo W. (2007) Robust modified Newton algorithm for adaptive frequency estimation. IEEE Trans Signal Process Lett, 14(11):879-882.

[9] Xue SY, Yang SX. (2009) Power system frequency estimation using supervised GaussNewton algorithm. Measurement, 42(1):28-37.

[10] Terzija VV, Stanojevic V. (2007) Two stage improved recursive Newton-type algorithm for power-quality indices estimation. IEEE Trans Power Delivery, 22(3):1351-1359.

[11] Jiang X, King J, Emadi A. (2004) A power harmonics detection approach based on least squares energy minimization principle. 30th Annual Conference of the IEEE Industrial Electronics Society, Busan, Korea, pp.2934-2938.

[12] Abu Al-Feilat EA, El Amin I, Bettayeb M. (1994) Power system harmonic estimation and comparative study. Elect. Power Syst. Res., 29:91-97.

[13] Pradhan AK, Routray A, Basak A. (2005) Power system frequency estimation using least mean square technique. IEEE Trans. Power Del., 20(3):1812-1816. 
[14] Dash PK, Swain DP, Routray A, Liew AC. (1996) Harmonic estimation in a power system using adaptive perceptrons. IEEE Proc- Gener. Transm. Distribut., 143(6):565-574.

[15] Joorabian M, Mortazavi SS, Khayyami AA. (2009) Harmonics estimation in a powersystem using a novel-hybrid least square-Adaline algorithm. Electric Power System Research, 79(1):107-116.

[16] Lai TL, Wei CZ. (1982) Least squares estimates in stochastic regression models with applications to identification and control of dynamic systems. Annals of Statistics, 10(1): 154166.

[17] Ding F, Xie XM, Fang CZ. (1996) Multi-innovation identification methods for time-varying systems. Acta Automatica Sinica, 22(1):85-91.

[18] Ding, F., Ding, T., Yang, J., \& XIAO, D. (2001). Performance of multi-innovation identification for attenuating excitation of stochastic systems. JOURNAL-TSINGHUA UNIVERSITY, 41(9), 115-117.

[19] Ding F, Chen T. (2007) Multi-innovation stochastic gradient identification methods. Proceedings of the 6th world congress on intelligent control and automation (WCICA2006), June 21-23, 2006, Dalian, China.

[20] Ding F, Chen H, Li M. (2007) Multi-innovation least squares identification methods based on the auxiliary model for MISO systems. Journal name??, 186(1)184-192.

[21] Passino KM. (2002) Bio-mimicry of bacterial Foraging for distributed optimization and control. IEEE Contr. Syst. Mag., 22(3):52-67.

[22] Ray, P. K., \& Subudhi, B. (2012). BFO optimized RLS algorithm for power system harmonics estimation. Applied Soft Computing, 12(8), 1965-1977.

[23] Bettayeb, M., \& Qidwai, U. (2003). A hybrid least squares-GA-based algorithm for harmonic estimation. Power Delivery, IEEE Transactions on, 18(2), 377-382.

[24] Sahoo, H. K., Sharma, P., \& Rath, N. P. (2011, December). Robust harmonic estimation using Forgetting Factor RLS. In India Conference (INDICON), 2011 Annual IEEE (pp. 1-5). IEEE.

[25] Park, D. J., Jun, B. E., \& Kim, J. H. (1991). Fast tracking RLS algorithm using novel variable forgetting factor with unity zone. Electronics Letters, 27(23), 2150-2151.

[26] Wang J. (2009) A variable forgetting factor RLS adaptive filtering algorithm. IEEE conference, Beijing. 27-29 Oct., pp1127-1130.

[27] Mishra S. (2005) A hybrid least square-fuzzy bacterial foraging strategy for harmonic estimation. IEEE Transactions on Evolutionary Computation, 9(1):61-73.

[28] Mishra S, Bhende CN. (2007) Bacterial foraging technique based optimized active power filter for load compensation. IEEE Transactions on Power Delivery, 22(1):457-465.

[29] Biswas, A., Dasgupta, S., Das, S., \& Abraham, A. (2007). A synergy of differential evolution and bacterial foraging optimization for faster global search. International Journal on Neural and Mass-Parallel Computing and Information Systems-Neural Network World, 17(6), 607626.

[30] Holland JH. (1975) Adaptation in natural and artificial systems. University of Michigan Press, Ann Arbor, USA.

[31] Kennedy J, Eberhart R. (1995) Particle swarm optimization. Proceedings of IEEE International Conference on Neural Networks, pp1942-1948.

[32] Storn R, Price K. (1997) Differential evolution - A simple and efficient heuristic for global optimization over continuous spaces. Journal of Global Optimization, 11(4):341-359. 


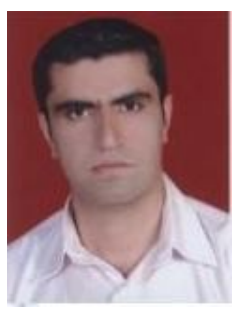

Ahmad Mohammadzade was born in Noor, Mazandaran, Iran in 1982.He received B.Sc. in power engineering from Islamic Azad University of Noor in 2012. He is currently is M.Sc. student in control engineering in Babol University of Technology, Babol, Iran. His research interests is system identification, heuristic optimization algorithms, and harmonic estimation in power system.

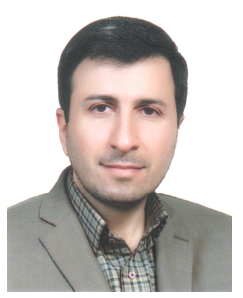

Jalil Sadati, was born in Behshahr, Mazandaran. He received M.Sc. degree in Ferdowsi University of Mashhad, and Ph.D. degree in Control engineering from University of Mazandaran, Iran in 2005 and 2011, respectivly. He is assistant professor of control engineering in the department of electrical and computer engineering of Babol University of Technology from 2011. His research interests are fractional-order control, time delay systems, nonlinear control, adaptive systems, and model predictive control.

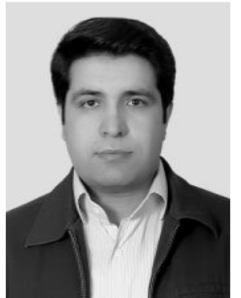

Behrooz Rezaie was born in Kermanshah in 1974. He received M.Sc. degree and Ph.D. degree in Control engineering from Iran University of Science and Technology, Tehran, Iran in 2001 and 2009, respectively. He is assistant professor of control engineering in the department of electrical and computer engineering of Babol University of Technology from 2010. His research interests are hybrid and complex nonlinear systems, and control theory and applications especially intelligent, adaptive and predictive control methods. 